ПРОБЛЕМИ ДИСТАНЦІЙНОГО КОРЕКЦІЙНО-РОЗВИТКОВОГО ПРОЦЕСУ: МОДИФІКАЦІЯ СПІВПРАЦІ ЛОГОПЕДА ТА БАТЬКІВ

\title{
THE ISSUES OF REMOTE CORRECTIONAL AND DEVELOPMENTAL PROCESS: MODIFICATION OF COOPERATION BETWEEN A SPEECH THERAPIST AND PARENTS
}

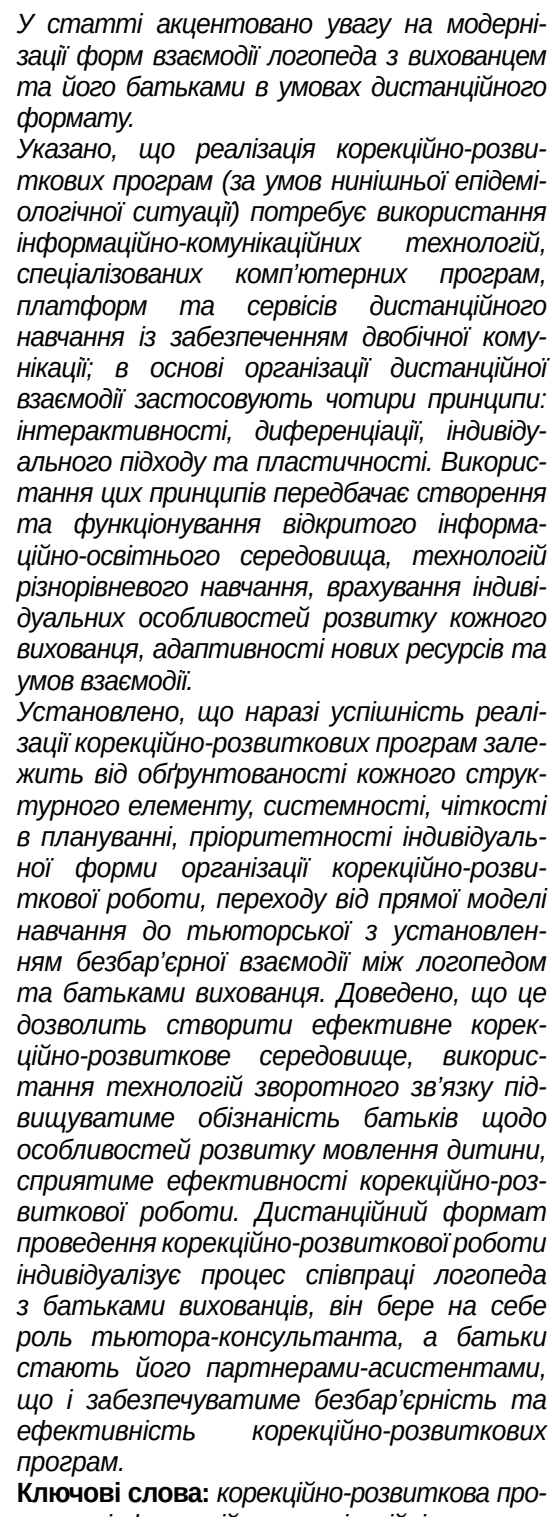
Ключові слова: корекційно-розвиткова про-
грама, інфоормаційно-комунікаційні техноло- гії, форми взаємодії, дистанційне навчання, інсрормаційно-освітнє середовище.

The article focuses on the modernization of forms of remote cooperation between a speech therapist and a pupil and his/her parents.

The author pointed out that the implementation of correctional and developmental programs in the current epidemiological situation requires the use of information and communication technologies, special software, platforms and e-learning services with two-way communication. The organization of remote interaction is based on four principles: interaction, differentiation, personal approach and flexibility. The application of these principles involves the creation and operation of open information and educational environment, multilevel learning technologies, taking into account the individual characteristics of each pupil, the adaptability of new resources and conditions of interaction.

The author found that the success of correctional and developmental programs in the current environment depends on the validity of each structural element, consistency, clarity in planning, the priority of personal forms of correctional and developmental work, the transition from a direct training model to tutoring with barrier-free cooperation between a speech therapist and parents of a pupil.

The author proved that the establishment of a partnership between a speech therapist and parents of a pupil will create an effective correctional and developmental environment, the use of feedback technologies will increase parents' awareness of the peculiarities of a child's speech development and the effectiveness of correctional and developmental work. The remote format of correctional and developmental work individualizes the cooperation between a speech therapist and parents, he takes on the role of tutor-consultant, and parents, in turn, become his partners-assistants, that will provide the inclusion and the effectiveness of corrective and developmental programs.

Key words: correctional and developmental program, information and communication technologies, interaction, e-learning, information and educational environment.
Уманського державного педагогічного університету імені Павла Тичини
Постановка проблеми в загальному вигляді. Інструктивно-методичні рекомендації Міністерства освіти і науки щодо організації навчання осіб з особливими освітніми потребами у 2020-2021 н. р. передбачають надання корекційно-розвиткових послуг дітям 3 особливими освітніми потребами у дистанційному фрорматі [12]. Нинішня епідеміологічна ситуація вимагає модернізації форм взаємодії логопеда з вихованцем та батьками, адаптації індивідуальних програм розвитку в умовах дистанційного формату, забезпечення двобічної комунікації з батьками щодо особливостей організації корекційно-освітнього процесу.

Аналіз останніх досліджень і публікацій. Одним із головних стратегічних завдань сучасності має бути якісна освіта, що є культурним фрундаментом суспільства - своєрідним соціальним генетичним механізмом трансляції соціального досвіду, завдяки якому стає можливою реалізація сутнісних сил людини, закладених у ній самою природою, і предметом уваги й розвитку. Дистанційний формат надання освітньо-корекційних послуг не має стати перепоною для забезпечення 
якісної взаємодії вихованця, батьків та логопеда, подолання бар'єрності в спілкуванні для реалізації завдань корекційно-розвиткової програми.

Проблеми пошуку універсальних парадигм взаємодії логопеда та батьків стали стрижнем наукового доробку І. Іванюк, В. Глухової, Н. Мовчан, А. Назаренко, В. Кисличенко, А. Король, Л. Стахової, О. Константинів, Ю. Рібцун та ін. Проблемам упровадження в освітній контент інформаційнокомунікаційних технологій, пошуку дієвих фрорм взаємодії присвячено праці В. Бикової, А. Король, Ю. Рібцун, С. Мировової, О. Цимбалюк, А. Литвин, В. Пасічник, Г. Федорук, М. Шишкіної та ін.

Т. Бардишева, М. Кислякова, Е. Китик, Л. Ковригіна, О. Нелюбіна, В. Пасічник, О. Потимко зауважують, що використання інформаційно-комунікаційних технологій у професійній підготовці майбутніх логопедів забезпечує орормування їх готовності до впровадження в корекційно-освітній процес спеціальних комп'ютерних програм, спрямованих на виконання професійних завдань.

Виділення не вирішених раніше частин загальної проблеми. Упровадження дистанційного фрормату в освітній простір об'єднало науковців для дискусійного пошуку таких нових моделей організації корекційно-розвиткового процесу, як використання інорормаційно-комунікаційних технологій, пошук універсальних парадигм взаємодії, використання спеціалізованих комп'ютерних програм, однак наразі фрахівці-практики потребують певної «дорожньої карти», в якій би надавалися практичні рекомендації щодо дієвості використання різноманітних платорорм та сервісів дистанційного навчання, варіативність у проєктувальному, організаторському та оціночному видах діяльності, створення своєрідної бази з практичними рекомендаціями щодо організації та забезпечення ефективності корекційно-розвиткової програми в дистанційний період.

Оновлення основних траєкторій співпраці логопеда з батьками вихованця в умовах дистанційного фрормату реалізації корекційно-розвиткової програми забезпечуватиме її високу результативність.

Мета статті - вказати на ключові зміни в побудові парадигми взаємодії логопеда та батьків вихованців у дистанційному фрорматі реалізації корекційно-розвиткової програми.

Виклад основного матеріалу. Успішність реалізації корекційно-розвиткової програми завжди базувалася на ключових цілях, обґрунтованості кожного структурного елементу, системності, чіткості в плануванні, а усвідомлене включення у цей процес батьків вихованця однозначно підвищувало результативність корекційного впливу [4].

Нинішні карантинні обмеження призводять до збільшення кількості дітей, що використовують віртуальний простір для ігрової активності, все більше занурюючись у нереалістично-ілюзорний світ, і, як наслідок, зумовлюють підвищений рівень тривожності та емоційних спалахів. Окрім викликів, що супроводжують дистанційний фрормат освіти, логопедові потрібно врахувати негативний вплив неконтрольованої ігрової активності вихованця. Особливого значення в сучасних умовах набуває усвідомлення логопедом принципово нових вимог до педагогічної діяльності та організації корекційної роботи з використанням інформаційно-комунікаційних технологій як розвиткового, корекційного, начального та виховного ресурсів [4], гарантуючи при цьому безпечне інорормаційне середовище.

На думку Л. Стахової, взаємодія логопеда та батьків передбачає розподіл завдань між учасниками корекційно-розвиткового процесу: усвідомлення батьками їх ролі в процесі розвитку дитини, визначення цікавих та доступних методів та прийомів подолання мовленнєвого порушення [9].

В. Кисличенко стверджує, що сучасні батьки, які виховують дитину 3 особливими освітніми потребами, зокрема 3 порушенням мовлення, виявляють недостатній рівень психолого-педагогічної підготовки, що перешкоджає успішності корекційно-розвиткової програми, знижуючи ефективність занять [1]. Дистанційний фрормат занять вимагає пріоритетності індивідуальної фрорми організації корекційно-розвиткової роботи зі зміною робочого часу логопеда (врахування зайнятості батьків), а контроль та зворотний зв'язок процесу має бути взаємозрозумілим, відвертим та ненав'язливим.

В основі організації дистанційної взаємодії лежить застосування чотирьох головних принципів: інтерактивності, диореренціації, індивідуального підходу та пластичності. Водночас відбувається перехід від прямої моделі навчання до тьюторської (застосовуючи весь механізм школи наставництва) (табл. 1).

Тьюторська модель наставника $€$ найбільш пріоритетною в дистанційному режимі співпраці. Австрійський педагог Г. Фігдор уважав, що основними помилками у взаємодії педагогів та батьків $€$ неусвідомлені конфрлікти батьків: втома на роботі, відсутність розуміння важливості спільного корекційно-розвиткового процесу, недостатність знань батьків щодо мовленнєвих порушень у дітей [9, с. 221].

Якщо дитина не сприймає логопеда, то вона буде давати відсіч і його діям, тому подолання безбар'єрності в спілкуванні, установлення довірливих стосунків з дитиною та її батьками стануть запорукою успішності корекційно-розвиткового процесу. Таким чином, логопед має скоординувати особистісний розвиток дитини у таких напрямах, як-от:

- організація педагогічної підтримки з урахуванням її індивідуальних проявів і особистісно значущої діяльності; 
Принципи дистанційного навчання

Таблиця 1

\begin{tabular}{|c|c|c|c|}
\hline інтерактивність & дисреренціація & індивідуалістичність & пластичність \\
\hline $\begin{array}{l}\text { Створення та функціону- } \\
\text { вання відкритого інформа- } \\
\text { ційно-освітнього середовища } \\
\text { (модель наставництва -пріо- } \\
\text { ритетна; застосування синх- } \\
\text { ронного та асинхронного } \\
\text { навчання; підбір наочного } \\
\text { матеріалу, визначення } \\
\text { сталості освітньо-корекцій- } \\
\text { ної програми; адаптивність } \\
\text { нових ресурсів. }\end{array}$ & $\begin{array}{l}\text { Застосування техно- } \\
\text { логій різнорівневого } \\
\text { навчання: визначення } \\
\text { навантаження; враху- } \\
\text { вання емоційного стану } \\
\text { вихованця; консульта- } \\
\text { ція батьків щодо розви- } \\
\text { тку дитини; презентація } \\
\text { візуальної підтримки. }\end{array}$ & $\begin{array}{l}\text { Укладання корекційно-розвитко- } \\
\text { вої програми має враховувати } \\
\text { форму порушення дитини з осо- } \\
\text { бливими освітніми потребами } \\
\text { та індивідуальні особливості } \\
\text { розвитку кожного вихованця, } \\
\text { особливості родинної взаємодії. }\end{array}$ & $\begin{array}{l}\text { Корекційно-розви- } \\
\text { ткова програма має } \\
\text { враховувати особли- } \\
\text { вості кожної дитини, } \\
\text { зокрема темп про- } \\
\text { ведення заняття, } \\
\text { адаптивність до нових } \\
\text { умов взаємодії. }\end{array}$ \\
\hline
\end{tabular}

Джерело: сформовано за [5]

- взаємодія педагогів у межах гуманістичної педагогіки і в умовах суб'єкт-суб'єктних відносин;

- комплексне планування корекційно-розвиткового процесу, що забезпечує спільну роботу фрахівців;

- відбір засобів і методів педагогічного забезпечення, що відповідають особистісному становленню дитини, створення атмосфери доброзичливості, емпатійності, рівноправної співпраці, в якій виховується дитина [7, с. 30].

Дистанційний фрормат навчання індивідуалізує освітньо-корекційні процеси, вимагає використання нових інфрормаційно-комунікаційних технологій для фрормування інформаційно-цифрової компетентності (вибір платформ, програм, створення презентаційно-наочного матеріалу) та застосування дистанційно-інтерактивних фрорм співпраці логопеда 3 батьками, забезпечуючи результативність корекційно-розвиткового процесу в логопедичній практиці [3]. Слушною є пропозиція А. Король щодо використання технології «Фідбек» (своєрідний зворотний зв'язок, обговорення з батьками як індивідуальна консультативна допомога, що в подальшому дозволить уникнути проблем у розумінні освітньо-корекційного процесу) для впровадження дистанційної фрорми роботи, що дасть змогу осучаснити традиційні підходи до представлення та взаємообміну інформацією [3, с. 52]. Сутність такої технології зводиться до систематизованого використання засобів масової інформації, інфрормаційно-комунікаційних та інтерактивних технологій, складниками взаємодії яких є інфрормування, консультування та зворотний зв'язок із боку батьків, тобто «фідбек» на кожну дію логопеда. «Фідбек» здійснюється у фрормах відеоконференцій (Zoom, Google Meet), заповнення спеціалізованих Google-срорм, обговорення тематичних блогів, у повідомленнях у меседжерах [3].

Використання такої технології взаємодії дозволить досягти взаєморозуміння у розв'язанні проблемних питань, що можуть виникнути у дистанційному фрорматі спілкування, створить повноцінне інорормаційно-освітнє середовище, надасть можливість логопедові контролювати перебіг мовленнєвого розвитку дитини, мотивуватиме батьків навчатися прийомів логопедичної допомоги [4].

В умовах глибокої модернізації освітніх систем використання дистанційних фрорм взаємодії та побудови освітньо-корекційних процесів актуалізує необхідність удосконалення підготовки та перепідготовки педагогічних кадрів, зокрема й кваліфікованих логопедів. Недостатня компетентність i, як наслідок, відсутність профресійної мобільності порушують питання створення цілісної системи професіоналізації, вдосконалення змісту, фрорм і процесів, у яких вона відбувається [8, с. 3]. Міністерство освіти і науки України спільно з Центром здоров'я і розвитку «Коло сім'ї» за підтримки українсько-швейцарського проєкту «Психічне здоров'я для України» (Mental Health for Ukraine) [5] для успішності забезпечення допомоги психолого-педагогічного супроводу дітей з особливими освітніми потребами продовжують надавати цикл семінарів, зокрема із забезпечення успішного дистанційного навчання.

Так, використання спеціальних комп'ютерних програм у роботі з дітьми з порушеннями мовленнєвого розвитку дозволяє розвивати фронематичні процеси, дрібну моторику, активізує пам'ять, мислення, увагу, розширює словниковий запас вихованців, збільшує їх мовленнєву активність, фрормує навички правильного мовлення. Комп'ютерні технології передбачають використання на заняттях мультимедійних презентацій, ігрових вправ та завдань відповідно до вікових можливостей і освітніх потреб вихованців. Послідовність зображень на екрані комп'ютера сприяє тому, що діти виконують вправи уважно і в повному обсязі. Використання елементів анімації, красивих картинок і «сюрпризних» моментів стимулює пізнавальну активність дітей, урізноманітнюючи корекційний процес. Той фракт, що діти отримують схвалення не тільки від логопеда, але й із комп'ютера у вигляді картинок-призів зі звуковим супроводом, суттєво впливає на ефрективність корекційної роботи [11]. 
Використання логопедом елементів комп'ютерних технологій дозволяє розв'язати низку ключових проблем сучасної корекційної педагогіки, зокрема й дистанційного фрормату (розроблення технологій виявлення співвідношення між розвитком і навчанням, розроблення нових педагогічних технологій виконання традиційних корекційних та освітніх завдань, розроблення нового змісту спеціальної освіти й адекватних методів навчання тощо).

Висновки. Необхідність переходу на дистанційний фрормат проведення занять стала викликом для всіх освітян. Пошук нових фрорм взаємодії логопеда з родиною дитини, яка має порушення мовленнєвого розвитку, модернізація традиційних фрорм співпраці $€$ перспективною для відкритого діалогу науковців та практиків. Основою для сучасних логопедичних практик $€$ інформаційнокомунікаційні технології 3 пошуком ефективних форм практичної взаємодії, розроблення спеціальних комп'ютерних програм для забезпечення ефективності корекційно-розвиткового процесу.

Установлення партнерських стосунків між логопедом та батьками вихованця дозволить створити еорективне корекційно-розвиткове середовище, використання технологій зворотного зв'язку підвищуватиме обізнаність батьків щодо особливостей розвитку мовлення дитини, мотивуватиме їх на допомогу, забезпечуватимете її вчасне надання, сприятиме ефективності корекційно-розвиткової роботи. Отже, дистанційний фрормат проведення корекційно-розвиткової роботи індивідуалізує процес співпраці логопеда 3 батьками вихованців. Логопед бере на себе роль наставника, консультанта, а батьки стають його партнерами-асистентами, що і забезпечуватиме безбар'єрність та ефективність корекційно-розвиткових програм.

\section{БІБЛІОГРАФІЧНИЙ СПИСОК:}

1. Кисличенко В.А. Робота логопеда 3 батьками у сучасних умовах. Науковий вісник МНУ імені B.О. Сухомлинського. Серія: Педагогічні науки. 2015. Вип. 3(50). С. 80-85.

2. Константинів О.В. Особливості вивчення готовності батьків до співпраці 3 логопедом. Науковий вісник МНУ імені В.О. Сухомлинського. Серія: Педагогічні науки. 2017. Вип. 3(58). С. 203-207.

3. Король А.В. Технологія «Фідбек» як засіб співпраці вчителя-логопеда з батьками. Вихова- тель-методист дошкільного закладу. 2016. № 11. C. 51-58.

4. Король А.В. Дистанційно-інтерактивні форми взаємодії логопеда з педагогами та батьками як умова підвищення результативності корекційно-розвиткового процесу. Молодий вчений. 2018. № 5.2 (57.2). C. 54-57.

5. МOH підвищує рівень обізнаності педагогів та фрахівців у сорері інклюзивної освіти. URL: https:// mon.gov.ua/ua/news/mon-pidvishuye-rivenobiznanosti-pedagogiv-ta-fahivciv-u-sferi-inklyuzivnoyiosviti (дата звернення: 21.01.2021).

6. Рібцун Ю.В. Співпраця вчителя-логопеда 3 батьками: молодша логопедична група для дітей із ЗНМ. Дефектологія. Особлива дитина: навчання та виховання. 2011. № 1. С. 33-37.

7. Ромусик М.Н. Личностно-ориентированный подход в коррекционно-логопедической работе с детьми младшего дошкольного возраста с общим недоразвитием речи : дис. ... канд. пед. наук : 13.00.03. Москва, 2011. 207 с.

8. Соботович Е.Ф. Речевое недоразвитие у детей и пути его коррекции: (дети с нарушением интеллекта и моторной алалией). Москва : Классик стиль, 2003. $160 \mathrm{c}$.

9. Стахова Л.Л. Взаємодія учителя-логопеда закладу дошкільної освіти із сім'єю дитини з порушенням мовленнєвого розвитку як вагомий засіб досягнення корекційної мети. Збірник наукових праць Херсонського державного університету. Серія: Педагогічні науки. 2017. Вип. 79(2). С. 219-222.

10. Федорович Л.О. Концептуальні засади підготовки логопеда до роботи з дітьми раннього віку у вищих навчальних закладах в умовах інтеграції в європейський освітній простір. Науковий часопис НПУ імені М.П. Драгоманова. Серія 19: Корекційна педагогіка та спеціальна психологія. 2012. Вип. 21. C. $286-290$.

11. Цимбал-Слатвінська С.В. Етапи становлення профресійної підготовки майбутніх логопедів у системі спеціальної освіти. Науковий вісник Миколаївського національного університету імені В.О. Сухомлинського. Педагогічні науки. Миколаїв : МНУ імені В. О. Сухомлинського, 2019. № 2 (65). С. 334-340.

12. Щодо організації навчання осіб з особливими освітніми потребами у закладах загальної середньої освіти у 2020/2021 навчальному році : Лист МOH України від 31 серпня 2020 р. № 1/9-495. URL: https:// mon.gov.ua/ua/npa/shodo-organizaciyi-navchannyaosib-z-osoblivimi-osvitnimi-potrebami-u-zakladahzagalnoyi-serednoyi-osviti-u-20202021-navchalnomurосі (дата звернення: 21.01.2021). 